
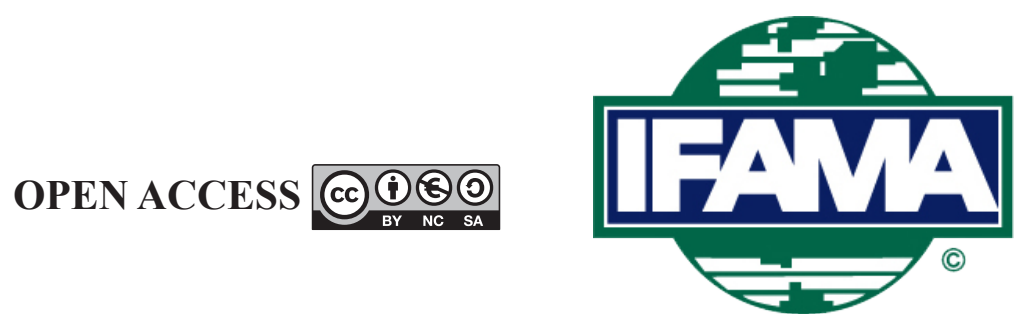

International Food and Agribusiness Management Review

Volume 24, Issue 5, 2021; DOI: 10.22434/IFAMR2019.0210

Received: 27 June 2018 / Accepted: 8 January 2021

\title{
Determinants of product innovation in food and agribusiness small and medium enterprises: evidence from enterprise survey data of India
}

\section{RESEARCH ARTICLE}

\author{
Jabir Ali ${ }^{\oplus a}$, Michael R. Reed ${ }^{\mathrm{b}}$ and Sayed H. Saghaian ${ }^{\mathrm{b}}$ \\ ${ }^{a}$ Professor, Economics \& Business Environment, Indian Institute of Management, \\ Old University Campus, Canal Road, Jammu - 180 016, Jammu and Kashmir, India \\ ${ }^{b}$ Professor, Department of Agricultural Economics, College of Agriculture, Food, and Environment, \\ University of Kentucky, 400 Charles E. Barnhart Bldg. Lexington, KY 40546-0276, USA
}

\begin{abstract}
This paper analyzes the nature and determinants of product innovation for food and agribusiness firms in India. The study is based on the World Bank's Enterprise Survey and the India Innovation Follow-up Survey from 2014. These surveys included 294 Indian food and agribusiness firms operating in different regions of the country. Simple statistical tools, such as chi-square test and logistic regression, are used for analyzing the raw data. It is evident from the analysis that there is a significant difference in the adoption of product innovations across enterprise sizes. Product innovation is more prominent in large enterprises than small and medium scale enterprises (SMEs). Results of regression analysis indicate that product innovation in SMEs is more likely to be influenced by a variety of internal, collaborative, and external factors. The findings of the study suggest that SMEs should diversify their product innovations to include new inputs, improved product features, and enhanced technologies to strengthen their place in the market. This research is valuable because there is limited evidence on the nature and determinants of product innovation in food and agribusiness SMEs of emerging economies like India.
\end{abstract}

Keywords: product, innovation, food and agribusiness, SMEs, India JEL code: L10, L66, O31, O53

\footnotetext{
(1)Corresponding author: jabirali@iimj.ac.in
} 


\section{Introduction}

Small and medium scale enterprises (SMEs) play a significant role in the growth and development of the overall economy for most Asian countries (Ali, 2016; Ayyagari et al., 2007; Berry et al., 2001; Cook and Nixson, 2000; Lin, 1998). The food and agribusiness sector in India, being a 'sunrise industry' due to high growth potential, is comprised of a large number of micro, small and medium enterprises, along with a small number of large enterprises and multinationals. All these entities compete with each other at all levels of business operations. According to the YES BANK-MoFPI-CII report (2016), the Indian food processing industry is estimated at US\$ 260 billion in revenue and growing at around $8 \%$ per annum. It accounts for over $9 \%$ of the manufacturing gross domestic product (GDP). As per the estimates of the Department of Industrial Policies and Promotion (DIPP), the food-processing sector in India has received around US\$ 7.47 billion worth of Foreign Direct Investment (FDI) during the period of 2000-16. SMEs are the key to strengthening the industrialization of the Indian food and agribusiness sector. There are about 51 million enterprises, employing about 117 million people (Ministry of Micro, Small \& Medium Enterprises, 2016). About $7 \%$ of these MSMEs belong to the food and agribusiness sector and they employ about $8 \%$ of the workforce. Food and agribusiness SMEs have huge potential to uplift the agricultural economy by generating employment and strengthening export earnings.

The food and agribusiness sector in India is largely unorganized and fragmented with many inefficiencies across the value chain. It is going through a significant transformation across all stages of business processes starting from raw material sourcing to customer service. In order to realize its full potential, the food and agribusiness sector needs to introduce innovations in farming practices, post-harvest technologies, adoption of food safety norms, new product development, and market linkages. The industry is characterized by rapidly changing consumer preferences for each product it offers (Suwannaporn and Speece, 2010). Innovation is increasingly recognized as an important initiative, which has contributed towards organizational success, business performance, and survival in the emerging market environment (Baregheh et al., 2012b; Felin et al., 2017; Lefebvre et al., 2015). Jozsef and Imre (2017) found that open innovation positively influences the performance of product and market innovations. New product innovation in the Indian food and agribusiness sector is becoming the key to sustained growth and development due to changing consumer tastes and preferences.

Lundvall (1992) defined innovation as an ongoing process of leaving, searching, and exploring which results in new products, new techniques, new forms of organization, and new markets. Considering the increasing importance of consumer preference on food product choices, this paper analyzes the factors affecting product innovation in the food and agribusiness segment. We choose product innovation for this study because many firms rely on this type of innovation to enhance their position in very competitive markets. Dhamvithee $e t$ al. (2005) argued that continual innovation in the form of new product development is critical to the food and agribusiness industry's growth and survival.

According to the World Bank Enterprise Survey (2014) product innovations include products that differ significantly in their characteristics or intended uses from products previously produced by the firm. A new product can use new technology or a new combination of existing technology. The development of a new use for a product with only minor changes to its technical specifications is also product innovation. Significant improvements to existing products can occur through changes in materials, components, and other characteristics that enhance performance. Product development is systematic, commercially oriented research to develop products and processes satisfying a known or suspected consumer need (Winger and Wall, 2006). Evidence indicates that product development is a complex process that requires an innovative approach for enhanced knowledge of ingredients, processing techniques, packaging materials, regulations, and consumer demands and preferences (Azanedo et al., 2020; Madzík, 2019; Ramadani et al., 2019).

This study aims at understanding the nature of product innovation adopted by the food and agribusiness sector across enterprise size in India and assessing the factors affecting the adoption of innovations for improving 
their competitiveness. This research is based on the World Bank's Enterprise Survey data of 294 food and agribusiness firms in India. This study contributes to the literature in two ways - identifying the nature and magnitude of product innovation across food and agribusiness firms and mapping the determinants of product innovation by looking at factors related to internal, collaborative, and external to the firms. The findings of the research provide key insights into food and agribusiness firms and policy-makers in strengthening product innovation among SMEs. This paper is organized into six sections. The background of the study is briefly explained in the first section of the paper followed by the section on the literature review. Based on the literature review and conceptual research framework, objectives, and hypotheses are provided in section three of the paper followed by the section on data and methods. Section four provides the results of the data analysis along with the discussion. Finally, conclusions and managerial implications of the study are given in the last section of the paper.

\section{Conceptual research framework and hypotheses}

Innovation is becoming key for business success across the sectors, including food and agribusiness (Baregheh et al., 2012a; Bayona-Saez et al., 2017; Fernández-Esquinas et al., 2017; Lefebvre et al., 2015; Ramadani et al., 2019). Baregheh et al. (2012b) defined innovation as the multistage process whereby organizations transform ideas into new/ improved products, services, or processes in order to advance, compete, and differentiate themselves successfully in their marketplace. Empirical evidence indicates that many factors affect the level of adoption of innovative business practices across the value chain. These factors range from microeconomic characteristics of the firm and inter-firm linkages with the value chain stakeholders to macro-economic environmental factors (Avermaete et al., 2003; Bougrain and Haudeville, 2002; Capitanio et al., 2009; Chang et al., 2011; Raymond and St-Pierre, 2010; Rhee et al., 2010; Snihur and Wiklund, 2018; Traill and Meulenberg, 2002; Vancauteren, 2018).

Nor et al. (2016) analyzed innovation barriers and risks for food processing SMEs in Malaysia using survey data from 247 firms. They found significant impacts on innovations from financial barriers in the forms of financial assistance from the government, high-interest rate, and complicated process of loan application for food processing SMEs in Malaysia. Rhee et al. (2010) argued that innovation is a key success factor in a firm's sustainable competitive advantage. They analyzed the drivers of innovativeness and performance for SMEs in South Korea. They concluded that market orientation and entrepreneurial orientation significantly influence learning orientation, which leads to the firm's performance. The findings of the study implied that managers with entrepreneurial orientation and market orientation should place much emphasis on learning orientation to boost innovativeness and ultimately achieve performance.

Toselli (2017) analyzed the factors affecting product and process innovation in Spanish food manufacturing firms with a focus on knowledge sources and integration ties. The study concluded that demand-pull affects the probability of achieving product innovation while technology-push affects the probability of both product and process innovation. De Martino and Magnotti (2018) analyzed the innovation capacity of SMEs and micro-enterprises of agrifood supply chains that address the influence of internal and external resources and argued the existence of three clusters/innovation modes (i.e. collaborative innovators (CIs), non-collaborative innovators (NCIs), and non-innovators (NIs)) in managing the agrifood supply chain. Bhuiyan et al. (2016) studied innovation as a driver that affects the performance and growth of food processing SMEs in Malaysia and concluded that innovation has significant positive impacts on new product development, new operational process, new managerial process, new markets, and new sources of supply in food processing SMEs. Triguero et al. (2013) assessed environmental and market determinants such as market changes or appropriability are more decisive factors influencing innovation in the food industry.

Several studies have analyzed the nature of product innovation across firm size and argued that large food and agribusiness firms have more and better resources for innovating their product and services based on consumer demand (Baregheh et al., 2012a; Dhamvithee et al., 2005; Garst et al., 2017; Herrmann, 1997; Muscio et al., 2010; Nazzaro et al., 2019). Others have analyzed the implication of internal, collaborative, 
and external factors affecting firm innovations (Abdirahman et al., 2014; Avermaete et al., 2003; Baregheh et al., 2012b; Feranita et al., 2017; Madzík, 2019; McAdam et al., 2016; Siriwongwilaichat and Winger, 2004;). Martinez and Briz (2000) stressed the importance of in-house technological capabilities in innovation performance for the Spanish Food \& Drink Industry. Carida and Colurcio (2014) analyzed the role of relationship in resource integration and the process of fostering network-based innovation in Italian food SMEs. Capitanio et al. (2009) argued that the driving factors of innovation in the food sector could be identified either in internal or external dynamics.

Van Kleef et al. (2005) argued that the inclusion of consumers' voices at early stages in the new product development process has been identified as a critical success factor for new product development. Suwannaporn and Speece (2010) further found that immediate adaptation to customer's needs is critical in the new product development process with an increasingly market-driven food economy. Capitanio et al. (2010) argued that most product innovations in the food industry are incremental rather than radical in order to meet the consumer's expectation. However, for gaining competitive advantages in emerging food markets, organizations have started focusing on radical innovations such as health-enhancing food products by creating benefits based on technological development (Hutahayan and Yufra, 2019; Kuzminov et al. 2018; Mark-Herbert, 2004; Ziggers, 2005). Siriwongwilaichat and Winger (2004) highlighted the necessity of technical knowledge for food product innovation in Thailand. Xu (2020) investigated a firm's incentive to innovate its basic product to be socially responsible and its decision on the product line.

This study aims at understanding the nature of product innovation adopted by the food and agribusiness sector across enterprise size in India and assesses the factors affecting the adoption of innovations for improving their competitiveness. Based on the literature review and objective of the study, four hypotheses have been formulated and are tested in the study. The relationship between firm size and level of innovation has widely been analyzed across the globe (Babutsidze, 2016; Bhattacharya and Bloch, 2004; Brouwer and Kleinknecht, 1996; Dooley et al., 2016; Hong et al., 2016; Restrepo-Morales et al., 2019; Rogers, 2004; Santarelli and Sterlacchini, 1990). Hansen (1992) assessed the role of firm size and age on the level of innovation in the manufacturing sector. Avermaete et al. (2003) demonstrated that innovation depends on the age of the firm, size of the firm, and regional economic performance indicators in Belgium. Teruel and Segarra-Blasco (2017) analyse the effect that firm size on gender diversity and the probability of innovating and concluded that the size of the firm plays a moderating role in gender diversity and innovation. Rogers (2004) argued that large firms may have access to a wider range of resources, knowledge, and human capital skills than small firms, allowing higher rates of innovation. However, small manufacturing firms exhibited a positive association between networking and innovation, and we, therefore, expect to accept Hypothesis 1.

H1: The product innovation in the food and agribusiness sector is significantly associated with the size of the enterprises.

Avermaete et al. (2003) argued that product innovation is normally influenced by changes in internal factors such as the organizational structure of a company. Internal factors such as firm age, type, size, product category, and employees are important indicators affecting the level of innovation in an organization. Bougrain and Haudeville (2002) assessed how SMEs' internal research capacities help them to exploit external scientific and technical knowledge and to use networks of innovators. They concluded that internal R\&D capacities enhance the firm's ability to co-operate and to carry its project to success. Capitanio et al. (2010) analyzed the product and process innovation in the Italian food industry and concluded that the driving factors of innovation in the food sector could be identified either in internal and external dynamics. Raymond and StPierre (2010) argued that improved management of R\&D, technology, and innovation constitutes a critical success factor for these enterprises in the changing business environment. They tested the relationship between R\&D and innovation empirically with survey data from 205 Canadian manufacturing SMEs. Their results confirm that the impact of R\&D on product innovation is mediated by process innovation. 
Macdonald et al. (2007) analyzed the impact of higher-level education and training for the employees of SMEs in providing the resources they require for strengthening innovation. They argued that improved education/training is necessary to ensure that innovation is feasible and viable. Manresa et al. (2019) analyzed the impact of training practices on innovation and financial performance and highlighted the benefits of implementing these types of practices on innovation performance. Muscio et al. (2010) studied organizational and environmental antecedents that influence the development of a balanced dimension of innovation ambidexterity leading to superior firm performance based on 1,000 SMEs in Scotland. They revealed that internal organizational structures in a highly dynamic environment stimulate the appearance of innovation dexterity through the creation of breakthrough products and processes. Thus, we hypothesize that internal factors within the firm, influence product innovation and expect to accept Hypothesis 2.

H2: Internal factors within the firms have a significant influence on the level of product innovation among food and agribusiness enterprises.

Several research studies indicate that innovations are effectively developed through the interplay between different parties from different organizations (Bhardwaj, 2019; Blog, 2017; Bougrain and Haudeville, 2002; Colurcio and Russo-Spena, 2013; Ko et al., 2018; Markovic et al., 2020; Segarra-Ciprés and Bou-Llusar, 2018; Trott and Hartmann, 2009). Collaborative participation in supply chain networks and engagement in partnerships are important for SMEs in managing the issues of new technologies and market frontiers, and cope with the fast-changing environment (Falahat et al., 2020; Haus-Reve et al., 2019; Narula, 2004). El Manzani et al. (2019) investigated the quality management system on product innovation that international quality certification systems prove to have a strong positive and significant impact on incremental product innovation and a weak positive and significant impact on radical product innovation. Minarelli et al. (2014) investigated the importance of networking across SMEs to meet their needs in terms of expertise, technology advancement, and access to financial resources with the main purpose of fostering innovation to enable them to meet increasing global competition. They tried to identify whether the firms within groups of SMEs behave the same in terms of innovation and provided an understanding of firm structure and innovation in Italian food SMEs. McAdam et al. (2016) explored the role of regional horizontal networks in agri-food SMEs in enhancing the capability and outcomes through the adoption of combined innovation and social network perspective. They necessitated the requirement of innovation-based knowledge exchange at different life cycles influenced by changes in network dynamics across SMEs.

Ueasangkomsate and Jangkot (2018) indicated that SME collaboration with the university, industry, and government had a positive effect on enhancing the innovation of Thai food manufacturing SMEs. Blog (2017) argued that most of the firms lack the necessary resources to enhance their innovation capabilities, so cooperating with other organizations or institutions is seen as a viable alternative. Lefebvre et al. (2015) indicated that collaboration with customers and market-based actors matter for product innovations in European food SMEs. Hoegl and Wagner (2005) analyzed the buyer-supplier collaboration in product development and concluded that it positively relates to product quality, adherence to product cost targets, adherence to development budgets, and adherence to development schedules. They argued that a strong buyer-supplier collaboration helps in achieving the goal of new product development in a sustainable manner. Therefore, we expect that collaborative factors among companies positively influence product innovations and that we will accept Hypothesis 3.

H3: Collaborative factors among enterprises significantly affect the level of product innovation among food and agribusiness enterprises.

Damanpour and Schneider (2009) argued that organizations are forced to innovate their business practices due to increasing pressure from the external business environment through competition, deregulation, resource scarcity, and customer demand. Macro-economic indicators are another set of influencing factors for innovations in SMEs, such as the institutional, technological, political, and legal environment (Strobel and Kratzer, 2017). Mention (2011) argued that innovation emerges from an interactive business process 
between the firms and the external business environment. Santoro et al. (2017) analyzed the role of external knowledge in the innovation process of Italian food and beverage firms; specifically, the effects of two external knowledge sources, (market and science-based sources) on new product development (NPD) performance. They concluded that R\&D intensity enhances the benefits of external knowledge sourcing modes. Trott and Simms (2017) argued that external sources influence the innovation process of low-and medium-technology (LMT) industries such as the packaged food sector and concluded that innovation is strengthened by establishing closer links between university and industry, which helps in building networking competencies. Fertő et al. (2016) analyzed the role of openness/external knowledge with regard to innovation and a firm's absorptive capacity for explaining innovative performance in the Hungarian food chain. They argued that openness along the food chain might decrease the introduction time for innovations in all areas. We believe that external factors are important in determining the level of product innovation among firms, so we expect to accept Hypothesis 4.

H4: External factors for the firms have a significant bearing on the level of product innovation among food and agribusiness enterprises.

Figure 1 provides the process of analyzing the determinants of product innovation in the food and agribusiness sector. The $\mathrm{H}$ labels reflect the hypotheses formulated and tested in the study.

\section{Data and methods}

\subsection{Data sources}

The World Bank's Enterprise Surveys offers an expansive array of economic data on 164,000 firms in 144 countries. The enterprise survey is conducted at the firm-level covering a broad range of business environment topics including access to finance, corruption, infrastructure, crime, competition, and performance measures. The business owners and top managers of the firms are included in the survey using a stratified random sampling technique. The strata for Enterprise Surveys were based on the firm size, business sector, and geographic regions to ensure a better representation of business enterprises. Geographic regions within the country were selected based on which cities/ regions collectively contain the majority of economic activity. Moreover, the confidentiality of the survey respondents is maintained to ensure the greatest degree of survey participation, integrity, and confidence in the quality of the data. The firm-level data along with the questionnaires and accompanying survey documentation is freely available for the researchers on the data portal of the World Bank.

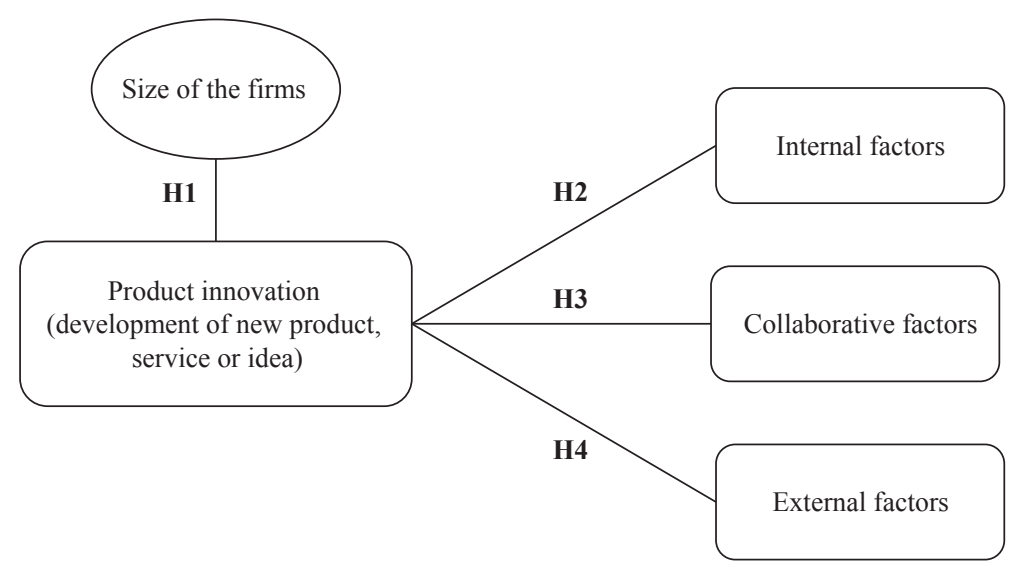

Figure 1. The null hypotheses for the determinants of product innovation. 
The present study is based on the survey data of 294 Indian food and agribusiness firms operating in different regions of the country. The data for food and agribusiness firms were extracted from the World Bank's Enterprise Survey and the India Innovation Follow-up Survey of 2014. The World Bank conducted a comprehensive Enterprise Survey of 9,281 firms of India and the India Innovation Follow-up Survey included 3,492 firms from different industry sub-sectors across the country. Under the Innovation Follow-up Survey, about $50 \%$ of the firms under the Enterprise Survey were re-visited to collect firm-level data on innovation and innovation-related activities. Firm-level food and agribusiness data were extracted after merging the datasets of both surveys based on the International Standard Industrial Classification using a unique common identification key of both the datasets. Food and agribusiness firms are comprised of manufacturers of food products and beverages, manufacturers of fertilizers, pesticides, and other agrochemical products, manufacturers of machinery and equipment and wholesalers, and retailers of food, beverages, and tobacco. Firm size is categorized by the World Bank based on the number of employees (i.e. 5-19 employees as a small enterprise, 20-99 employees as a medium enterprise, and 100 and above employees as a large-sized enterprise).

\subsection{Survey instrument and description of variables}

Data were collected under World Bank's Enterprise Survey, using two survey questionnaires - Enterprise Survey and the India Innovation Follow-up Survey. Required sections of these survey questionnaires, such as: (1) basic profile and nature of business units; (2) components of business innovation; and (3) constraints in doing business and factors affecting innovations are utilized. Table 1 provides the descriptive statistics of the variables used for analysis. The firm's responses on the nature and reasons for product innovation are used for the analysis. Under the study, product innovation has occurred if the firm records: (a) products or services that are new to the establishment; or (b) products or services that have significant improvements in capabilities, user-friendliness, components, or sub-systems. Further, determinants of product innovation are identified from the survey questionnaires based on the conceptual research framework and hypotheses. Information on enterprise characteristics, firm performance indicators, and the firm's investment in research and development (R\&D) are internal factors likely to affect the adoption of product innovation in food and agribusiness firms. The performance of firms has been measured with indicators such as growth in sales, employment, labor productivity, and capacity utilization.

A set of collaborative factors are included in the study, whether a third party is involved in cooperating with the firms for such things as international certification, the loan from banks, external R\&D, membership in an industry association, formal training, cooperation for innovation, collaboration with suppliers, and membership in a trade association. Collaboration is a practice where firms work together for a common purpose to achieve a business benefit, which involves some combination of risk sharing, obtaining access to new markets and technologies, speeding products to market, and pooling complementary skills (Powell et al., 1996). Further, information on a set of 16 business obstacles, as reported by the firms on a 5-point rating scale (where $1=$ no obstacle, 2 = minor obstacle, $3=$ moderate obstacle, $4=$ major obstacle, $5=$ very severe obstacle), have been categorized into three groups - access to resources (land, finance, electricity, telecommunications, and transport), regulatory systems (customs and trade regulations, tax rates, tax administrations, business licensing and permits, labor regulations, and courts), and business externalities (crime, theft and disorder, competition, political instability, corruption, and inadequately educated workforce). These three obstacles were used as external factors affecting product innovation in food and agribusiness firms. Further, these variables have been transformed into binary variables with $0=$ no obstacle and $1=$ obstacles.

\subsection{Data analysis}

Based on the research objectives and hypotheses, simple statistical tests are used to analyze the raw data. The Chi-square test is used to analyze the difference in the nature of product innovations adopted by food and agribusiness enterprises by size, which is the most commonly used tool for dichotomous variables (Simmons et al., 2007; Suwannaporn and Speece, 2010). Further, a logistic regression model is developed to identify 
Table 1. Descriptive statistics of variables.

\begin{tabular}{|c|c|c|c|c|c|c|}
\hline Variables & Code & $\mathbf{n}$ & Minimum & Maximum & Mean & $\begin{array}{l}\text { Standard } \\
\text { deviation }\end{array}$ \\
\hline Product innovation $($ yes $=1$, otherwise $=0$ ) & PI & 294 & 0 & 1 & 0.54 & 0.499 \\
\hline \multicolumn{7}{|l|}{ Internal factors } \\
\hline Age of the firm (years) & Age & 294 & 1 & 87 & 20.58 & 15.847 \\
\hline $\begin{array}{l}\text { Firm type (sole proprietorship }=1 \text {, } \\
\text { otherwise }=0 \text { ) }\end{array}$ & FTYPE & 294 & 0 & 1 & 0.50 & 0.501 \\
\hline Annual sales growth (\%) & ASG & 294 & -36 & 56 & 5.85 & 9.562 \\
\hline Annual employment growth (\%) & AEG & 294 & -12 & 124 & 5.29 & 10.766 \\
\hline Annual labor productivity growth (\%) & LPG & 294 & -24 & 14 & 0.20 & 3.256 \\
\hline Capacity utilization (\%) & $\mathrm{CU}$ & 248 & 0 & 100 & 80.96 & 17.549 \\
\hline Internal $\mathrm{R} \& \mathrm{D}(\mathrm{yes}=1$, otherwise $=0)$ & IRD & 294 & 0 & 1 & 0.32 & 0.468 \\
\hline Collaborative factors & & & & & 0.35 & \\
\hline $\begin{array}{l}\text { International certification }(\mathrm{yes}=1 \text {, } \\
\text { otherwise }=0 \text { ) }\end{array}$ & CERT & 294 & 0 & 1 & 0.40 & 0.478 \\
\hline Loan from banks (yes $=1$, otherwise $=0$ ) & LOAN & 294 & 0 & 1 & 0.07 & 0.490 \\
\hline External R\&D (yes $=1$, otherwise $=0)$ & ERD & 294 & 0 & 1 & 0.65 & 0.252 \\
\hline $\begin{array}{l}\text { Industry association (yes }=1 \text {, } \\
\text { otherwise }=0 \text { ) }\end{array}$ & IA & 294 & 0 & 1 & 0.37 & 0.478 \\
\hline Formal training (yes $=1$, otherwise $=0$ ) & FT & 294 & 0 & 1 & 0.18 & 0.484 \\
\hline $\begin{array}{l}\text { Cooperation for innovation (yes }=1 \text {, } \\
\text { otherwise }=0 \text { ) }\end{array}$ & COOP & 294 & 0 & 1 & 0.40 & 0.388 \\
\hline $\begin{array}{l}\text { Collaboration with suppliers (yes }=1 \text {, } \\
\text { otherwise }=0 \text { ) }\end{array}$ & SUP & 294 & 0 & 1 & 0.18 & 0.490 \\
\hline Trade associations $($ yes $=1$, otherwise $=0$ ) & TAW & 294 & 0 & 1 & 20.58 & 0.385 \\
\hline \multicolumn{7}{|l|}{ External Factors } \\
\hline $\begin{array}{l}\text { Access to resources (no obstacle }=0 \text {, } \\
\text { obstacle }=1 \text { ) }\end{array}$ & $\mathrm{AR}$ & 294 & 0 & 1 & 0.97 & 0.182 \\
\hline $\begin{array}{l}\text { Business regulations (no obstacle }=0 \text {, } \\
\text { obstacle }=1 \text { ) }\end{array}$ & $\mathrm{BR}$ & 294 & 0 & 1 & 0.96 & 0.198 \\
\hline $\begin{array}{l}\text { Market externalities (no obstacle }=0 \text {, } \\
\text { obstacle }=1 \text { ) }\end{array}$ & $\mathrm{ME}$ & 294 & 0 & 1 & 0.97 & 0.163 \\
\hline
\end{tabular}

the factors affecting the adoption of product innovation across enterprise sizes. Several empirical studies have used logistics regression for identifying the determinants of innovation in SMEs (Avermaete et al., 2003; Dries et al., 2013). Dhamvithee et al. (2005) used Poisson regression to investigate the determinants of innovation and a Least Squares regression to explain success rates in innovation. Rhee et al. (2010) applied structural equation modeling techniques to identify the drivers of innovativeness and performance for innovative SMEs. The empirical model for analyzing the factors influencing the product innovation in food and agribusiness SMEs is defined as:

$$
\ln (P /(1-P))=\alpha+\sum_{i=1}^{n} \beta_{i} X_{i}+\varepsilon_{i}
$$

Where $P$ is probability of product innovation adoption in food and agribusiness firms and $X_{i}$ is a vector of explanatory variables (internal, collaborative, and external environment), which are likely to influence the innovation; $\alpha$ is the intercept; $\beta_{i}$ is coefficient for $X_{i}$ and $\varepsilon_{i}$ is the error term. 


\section{Results and discussion}

\subsection{Enterprise characteristics by size}

Out of the 294 food and agribusiness enterprises extracted from the World Bank's Enterprise Survey for India, about $43.2 \%$ were small, $37.8 \%$ were medium, and $19.0 \%$ were large firms. Table 2 provides details on enterprise characteristics by size in terms of location, type, age, and product category of the firms. The chi-square statistics indicate that there is a significant association between the characteristics and size of the firms. It is clear from the analysis that small and medium enterprises are in bigger cities to access the markets efficiently as compared to large enterprises; however, there is no significant difference in the size of the firms across the locations. Female-owned firms were categorized as firms having at least one female owner in the firm. It is interesting to note that female ownership was comparatively higher in large firms $(30.4 \%$

Table 2. Enterprise characteristics by size. ${ }^{1}$

\begin{tabular}{|c|c|c|c|c|c|c|c|}
\hline \multirow[t]{2}{*}{ Indicators } & \multicolumn{2}{|c|}{$\begin{array}{l}\text { Small and medium } \\
\text { enterprises }(n=238)\end{array}$} & \multicolumn{2}{|c|}{$\begin{array}{l}\text { Large enterprises } \\
(\mathrm{n}=56)\end{array}$} & \multirow[t]{2}{*}{ Chi-square } & \multirow[t]{2}{*}{ df } & \multirow[t]{2}{*}{$P$-value } \\
\hline & $\mathbf{n}$ & $\%$ & $\mathbf{n}$ & $\%$ & & & \\
\hline \multicolumn{8}{|l|}{ Size of locality } \\
\hline City with population over 1 million & 74 & 31.1 & 12 & 21.4 & 5.443 & 3 & 0.142 \\
\hline Over 250,000 to 1 million & 81 & 34.0 & 18 & 32.1 & & & \\
\hline 50,000 to 250,000 & 60 & 25.2 & 15 & 26.8 & & & \\
\hline Less than 50,000 & 23 & 9.7 & 11 & 19.6 & & & \\
\hline \multicolumn{8}{|l|}{ Female participation in ownership } \\
\hline Yes & 26 & 10.9 & 17 & 30.4 & $13.710 * * *$ & 1 & 0.000 \\
\hline No & 212 & 89.1 & 39 & 69.6 & & & \\
\hline \multicolumn{8}{|l|}{ Type of firm } \\
\hline Limited company & 13 & 5.5 & 15 & 26.8 & $27.326^{* * *}$ & 3 & 0.000 \\
\hline Sole proprietorship & 129 & 54.2 & 18 & 32.1 & & & \\
\hline Partnership & 91 & 38.2 & 23 & 41.1 & & & \\
\hline Others & 5 & 2.1 & 0 & 0.0 & & & \\
\hline \multicolumn{8}{|l|}{ Age of the firm } \\
\hline$<10$ years & 72 & 30.3 & 11 & 19.6 & $17.418^{* * *}$ & 3 & 0.001 \\
\hline $10-20$ years & 83 & 34.9 & 12 & 21.4 & & & \\
\hline $21-30$ years & 49 & 20.6 & 12 & 21.4 & & & \\
\hline$>30$ years & 34 & 14.3 & 21 & 37.5 & & & \\
\hline \multicolumn{8}{|l|}{ Internal R\&D } \\
\hline Yes & 63 & 26.5 & 32 & 57.1 & $19.500 * * *$ & 1 & 0.000 \\
\hline No & 175 & 73.5 & 24 & 42.9 & & & \\
\hline \multicolumn{8}{|l|}{ Quality certification } \\
\hline Yes & 67 & 28.2 & 36 & 64.3 & $26.007 * * *$ & 1 & 0.000 \\
\hline No & 171 & 71.8 & 20 & 35.7 & & & \\
\hline \multicolumn{8}{|l|}{ Product category } \\
\hline $\begin{array}{l}\text { Manufacturer of food and } \\
\text { beverages }\end{array}$ & 168 & 70.6 & 44 & 78.6 & 2.239 & 2 & 0.326 \\
\hline $\begin{array}{l}\text { Manufacturer of fertilizers, } \\
\text { pesticides and machinery and } \\
\text { equipment }\end{array}$ & 30 & 12.6 & 7 & 12.5 & & & \\
\hline $\begin{array}{l}\text { Wholesale and retail of food and } \\
\text { beverages }\end{array}$ & 40 & 16.8 & 5 & 8.9 & & & \\
\hline
\end{tabular}


as compared to $10.9 \%$ in SMEs, $\chi^{2}=13.710, P<0.01$ ), implying that food and agribusiness SMEs are largely owned by males. Most of the Indian food and agribusiness SMEs are owned by a single proprietor and the majority of the proprietors are male. The distribution of firms by type of ownership also associated with the size of enterprises $\left(\chi^{2}=27.326, P<0.01\right)$. Most of the small and medium enterprises are sole proprietary or partnership firms whereas more large enterprises are limited liability companies, which gives them more opportunity for enhancing investment through public equity.

The distribution of enterprises by age across firm size also associated significantly $\left(\chi^{2}=17.418, P<0.01\right)$. It is interesting to note that the share of small and medium firms declines as the age of the firm increases; large firms are comparatively older. This may simply reflect the fact that successful SMEs become large firms over time. Internal investment for R\&D have a significant relationship across firm size $\left(\chi^{2}=19.500\right.$, $P<0.01)$. It is clear from the analysis that more than $57 \%$ of large firms have reported spending on R\&D as compared to about $26 \%$ of SMEs. Large firms are more inclined to adopt quality certification for their products and processes to enhance their performance and competitiveness $\left(\chi^{2}=26.007, P<0.01\right)$. More than $64 \%$ of large firms have reported the adoption of quality certification as compared to about $28 \%$ of the SMEs. The distribution of firms did not vary significantly by product category $\left(\chi^{2}=2.239, P>0.11\right)$. A closer look at the analysis indicates that the majority of the firms are food and beverage firms followed by the manufacturer of fertilizers, pesticides and machinery and equipment, and wholesalers and retailers of food and beverages.

\subsection{Nature of product innovation}

Production innovation and new product development are a continuous phenomenon for food and agribusiness firms because it helps determine the competitiveness of the firms in current rapidly changing consumer markets (Busse and Siebert, 2018; Dhamvithee et al., 2005; Fouad et al., 2018; Martinez and Briz, 2000; Suwannaporn and Speece, 2000). In today's business environment, new product development and innovation are largely consumer-driven and market-driven, and most organizations prefer a co-creation process for developing new products by involving the customers and suppliers (Antikainen and Niemelä, 2014; Bettiga and Ciccullo, 2018; Filieri, 2013; Hoyer et al., 2010; Jaeger et al., 2003; Siro et al., 2008; Søndergaard, 2005).

The result of the chi-square test on the survey data indicates that there are significant associations in adopting product innovations in food and agribusiness firms across sizes (Table 3). Product innovation is more prominent in large enterprises as compared to SMEs. A closer look at the analysis indicates that $77 \%$ of large food and agribusiness firms have reported a product innovation as compared to only $51 \%$ of the small and medium firms $\left(\chi^{2}=11.994, P<0.01\right)$. Furthermore, the number of products innovated by the firms vary by firm size. Most of the firms reported innovating a single product across firm sizes mainly through enhancement in the quality of the product. However, the intensity of product innovation is reported to be higher in SMEs, though not statistically significant.

Table 3. Product innovation by the size of firms. ${ }^{1}$

\begin{tabular}{|c|c|c|c|c|c|c|c|}
\hline \multirow[t]{2}{*}{ Product innovation } & \multicolumn{2}{|c|}{ SMEs } & \multicolumn{2}{|c|}{ Large } & \multicolumn{3}{|c|}{ Chi-square tests } \\
\hline & $\mathbf{n}$ & $\%$ & $\mathbf{n}$ & $\%$ & Value & df & Sig. \\
\hline \multicolumn{8}{|c|}{ Introduction of innovative product or service } \\
\hline Yes & 122 & 51.3 & 43 & 76.8 & $11.994 * * *$ & 1 & 0.001 \\
\hline No & 116 & 48.7 & 13 & 23.2 & & & \\
\hline \multicolumn{8}{|l|}{ Number of innovative products } \\
\hline One product & 78 & 63.9 & 29 & 67.4 & 0.378 & 2 & 0.828 \\
\hline Two products & 22 & 18.0 & 6 & 14.0 & & & \\
\hline More than two products & 22 & 18.0 & 8 & 18.6 & & & \\
\hline
\end{tabular}

$1 * * *$ significant at 0.01 level. 
About $36 \%$ of food and agribusiness SMEs have reported the adoption of product innovation in two or more products, whereas about $32 \%$ of the large firms have reported innovation in two or more products. An analysis of firm responses on the nature of product innovations indicates that most firms have innovated their products to enhance their quality, followed by the use of different inputs, in the process of developing new products (Figure 2). There is no statistical difference between the nature of product innovation by the size of firms. However, SMEs primarily focus on innovations in product quality, while the nature of innovation for large firms is more diversified through changing inputs, adding new attributes/functions, and adopting new technologies (Figure 2).

Responses on the reasons for product innovation in food and agribusiness firms are depicted in Figure 3: both SMEs and large firms have responded similarly. Product innovations are normally undertaken by the firm to extend the range of products offered (95\%) as well as to open new markets and enhance market share (87\%). The Indian food and agribusiness sector has been focusing on incremental innovations. However, the Indian agribusiness sector has huge potential for promoting radical innovations through launching a new range of health and wellness food products. About $73 \%$ of firms have reported the adoption of product innovation to compete in the market. As the regulatory environment for the food and agribusiness sector in India is becoming more robust, about $48 \%$ of firms have reported the adoption of product innovation to comply with regulations and standards. Hypothesis 1, which states that there is significant association

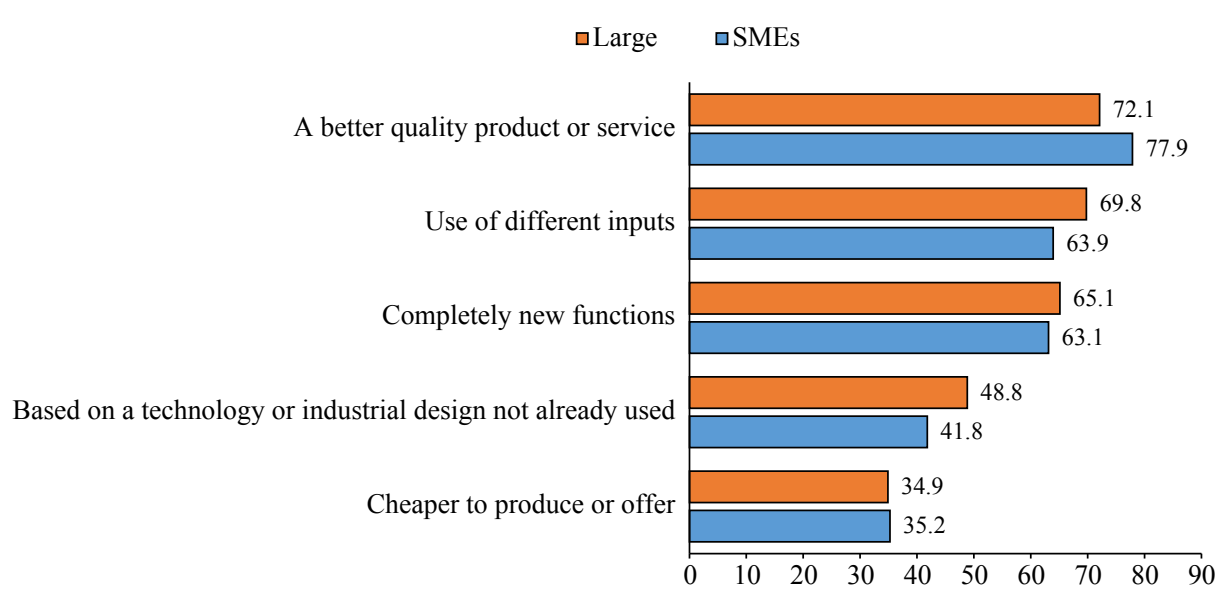

Figure 2. Nature of product innovation in food and agribusiness sector by firm size (\% saying 'yes').

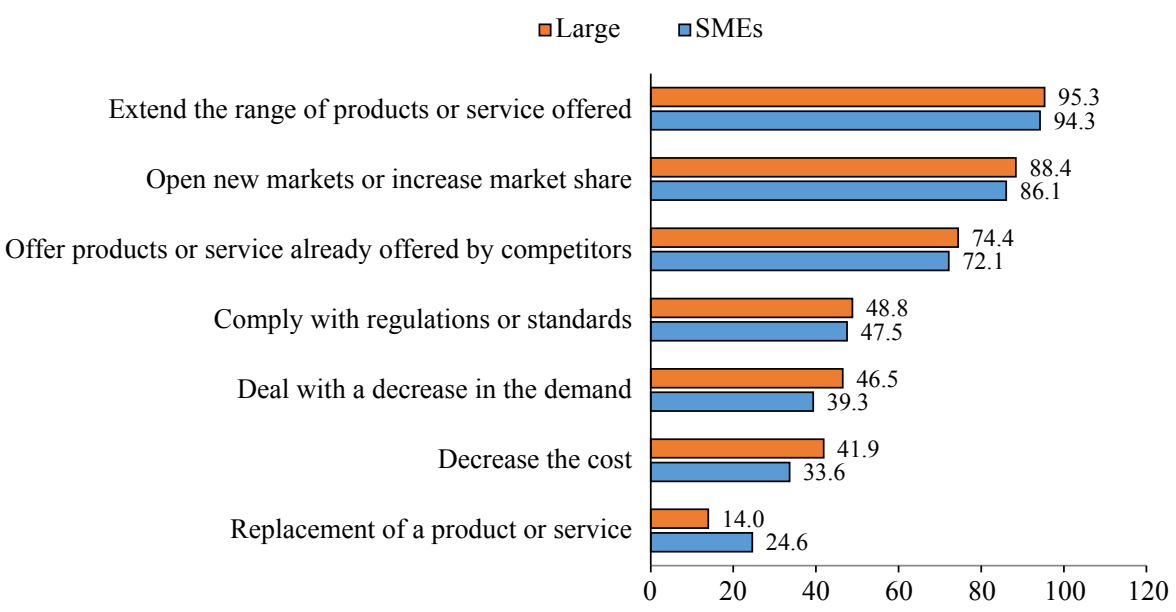

Figure 3. Reasons for product innovation in food and agribusiness sector by firm size (\% saying 'yes'). 
between in product innovation in the food and agribusiness sector across enterprise size, is accepted as a comparatively higher percentage of large firms (76.8\%) are focusing on product innovation (Table 2), as compared to smaller firms (51.3\%).

\subsection{Factors affecting product innovation in food and agribusiness}

In order to identify the relative importance of factors affecting product innovation, two regression models have been estimated - one for food and business SMEs and the other for the full sample of food and agribusiness firms. Table 4 reports the coefficients, their standard errors, and the marginal effects. The coefficients of marginal effects are estimated based on the logistic regressions. Marginal effects show the change in probability when the predictor or independent variable increases by one unit. The regression has 18 explanatory variables belonging to internal factors, collaborative factors (international certification, the loan from banks, external $\mathrm{R} \& \mathrm{D}$, industry association, formal training, cooperation for innovation, collaboration with suppliers, trade associations), and external factors (access to resources such as land and finance, business regulations, market externalities). Product innovation in SMEs is mostly influenced by only two variables - firm type and cooperation for innovation. The results of the regression analysis indicate that out of 18 independent variables, 8 variables are found to have a significant impact on product innovation in the case of all the

Table 4. Regression estimate - determinants of food \& agribusiness product innovation. ${ }^{1,2}$

\begin{tabular}{|c|c|c|c|c|c|c|c|c|c|c|c|c|}
\hline \multirow[t]{2}{*}{ Variables } & \multicolumn{6}{|l|}{ SMEs } & \multicolumn{6}{|l|}{ Overall } \\
\hline & $\beta_{\mathrm{s}}$ & S.E. & $|\mathbf{z}|$ & $P>|z|$ & MRE & $P>|z|$ & $\beta_{\mathrm{s}}$ & S.E. & $|\mathbf{z}|$ & $P>|z|$ & MRE & $P>|z|$ \\
\hline$A G E$ & 0.016 & 0.013 & -0.010 & 0.225 & 0.003 & 0.219 & 0.004 & 0.009 & 0.400 & 0.688 & 0.001 & 0.688 \\
\hline FTYPE & $0.792 * *$ & 0.340 & 0.125 & 0.020 & $0.156^{* * *}$ & 0.014 & $0.658 * *$ & 0.301 & 2.190 & 0.029 & $0.132 * *$ & 0.024 \\
\hline$A S G$ & -0.064 & 0.185 & -0.427 & 0.729 & -0.013 & 0.729 & -0.085 & 0.171 & -0.500 & 0.617 & -0.017 & 0.617 \\
\hline$A E G$ & 0.129 & 0.203 & -0.268 & 0.525 & 0.025 & 0.523 & 0.138 & 0.186 & 0.750 & 0.456 & 0.028 & 0.454 \\
\hline$L P G$ & 0.376 & 0.738 & -1.070 & 0.611 & 0.074 & 0.610 & 0.429 & 0.676 & 0.630 & 0.526 & 0.086 & 0.524 \\
\hline$C U$ & $-0.018^{*}$ & 0.010 & -0.037 & 0.056 & $-0.004^{* *}$ & 0.048 & -0.006 & 0.008 & -0.730 & 0.463 & -0.001 & 0.461 \\
\hline$I R D$ & 0.541 & 0.421 & -0.285 & 0.200 & 0.107 & 0.193 & $0.664 *$ & 0.359 & 1.850 & 0.064 & $0.133^{*}$ & 0.058 \\
\hline CERT & 0.425 & 0.372 & -0.304 & 0.253 & 0.084 & 0.247 & $0.798 * * *$ & 0.325 & 2.460 & 0.014 & $0.161 * * *$ & 0.010 \\
\hline$L O A N$ & 0.196 & 0.338 & -0.465 & 0.561 & 0.039 & 0.559 & 0.007 & 0.295 & 0.020 & 0.982 & 0.001 & 0.982 \\
\hline$E R D$ & -0.080 & 0.808 & -1.663 & 0.921 & -0.016 & 0.921 & 0.085 & 0.645 & 0.130 & 0.896 & 0.017 & 0.896 \\
\hline$I A$ & -0.289 & 0.371 & -1.016 & 0.436 & -0.057 & 0.433 & -0.197 & 0.330 & -0.600 & 0.550 & -0.040 & 0.549 \\
\hline$F T$ & 0.339 & 0.394 & -0.434 & 0.390 & 0.067 & 0.388 & -0.086 & 0.349 & -0.250 & 0.805 & -0.017 & 0.805 \\
\hline COOP & $-1.113 * * *$ & 0.455 & -2.004 & 0.014 & $-0.220 * * *$ & 0.009 & $-0.957 * * *$ & 0.386 & -2.480 & 0.013 & $-0.192 * * *$ & 0.009 \\
\hline SUP & 0.589 & 0.397 & -0.190 & 0.138 & 0.116 & 0.131 & $0.595^{*}$ & 0.312 & 1.910 & 0.056 & $0.120 * *$ & 0.050 \\
\hline$T A W$ & 0.728 & 0.519 & -0.288 & 0.160 & 0.144 & 0.153 & $1.006^{* *}$ & 0.416 & 2.420 & 0.016 & $0.202 * * *$ & 0.012 \\
\hline$A T R$ & 0.656 & 0.507 & -0.338 & 0.196 & 0.129 & 0.189 & 0.272 & 0.414 & 0.660 & 0.511 & 0.055 & 0.510 \\
\hline$G R$ & $0.962 *$ & 0.517 & -0.051 & 0.063 & $0.190 * *$ & 0.054 & $0.814 *$ & 0.448 & 1.820 & 0.069 & $0.164 *$ & 0.063 \\
\hline$E E$ & $-1.372 * * *$ & 0.546 & -2.441 & 0.012 & $-0.271 * * *$ & 0.008 & $-1.042 * *$ & 0.445 & -2.340 & 0.019 & $-0.209 * *$ & 0.015 \\
\hline$L L$ & -113.72 & & & & & & -145.55 & & & & & \\
\hline Obs. & 197 & & & & & & 248 & & & & & \\
\hline$L R-\chi^{2}$ & $\begin{array}{l}45.25 * * * \\
(0.00)\end{array}$ & & & & & & $\begin{array}{l}52.29 * * * \\
(0.00)\end{array}$ & & & & & \\
\hline
\end{tabular}

${ }^{1}$ This table reports the marginal effects for full samples and SMEs. ***, ** and * show 1, 5 and $10 \%$ level of significance, respectively. $P$-values are given in the parenthesis. $\beta_{s}$ indicates the coefficients of the independent variables.

${ }^{2} A E G=$ annual employment growth; $A S G=$ real annual sales growth; $A T R=$ access to resources; $C E R T=$ international certification; $C O O P=$ cooperation for innovation; $C U=$ capacity utilization; $E E=$ market externalities; $E R D=$ external $\mathrm{R} \& \mathrm{D} ; F T=$ formal training; FTYPE = firm type; $G R=$ business regulations; $I A=$ industry association; $I R D=$ internal R\&D; $L L=\log$-likelihood; $L O A N$ $=$ loan from financial institution; $L P G=$ annual labor productivity growth; $M R E=$ marginal effects; S.E. $=$ standard error; $S U P=$ collaboration with suppliers; $T A W=$ trade associations. 
firms. For instance, firm type (FTYPE) has a positive and significant marginal effect on product innovation implying that sole proprietorship firms are more likely to adopt product innovation by 13 percentage points. Similarly, internal R\&D (IRD), international certification (CRET), trade associations (TAW), collaboration with suppliers $(S U P)$, and business regulations $(G R)$ have positive marginal effects on product innovation. In contrast, we find a negative and significant marginal impact of innovation in cooperation $(C O O P)$ and market externalities $(E E)$ on full firms' product innovation.

The results of the regression analysis for factors affecting product innovation in food and agribusiness SMEs indicate that out of 18 explanatory variables, 5 variables are found to have a significant impact on product innovation. In the case of SMEs, our results show that capacity utilization $(C U)$, cooperation for innovation $(C O O P)$, and market externalities $(E E)$ have a negative and significant marginal impact on SMEs' product innovation, which is similar to the results for full sample except that the coefficient on CU is not significant in the full sample. It can be inferred from the analysis that food and agribusiness SMEs possess limited capabilities and their capacity utilization inversely affects adoption of product innovation. If their capacity is increasingly utilized the firms may feel less pressure to innovate. These small firms being at a nascent stage perceive that cooperation for innovation $(C O O P)$ may take away their independence or some other aspect of their business that they may feel is compromised through collaboration. Market externalities, such as market competition, political instability and corruption, are critical hurdles in adopting product innovation.

On the other hand, our results show that firm type (FTYPE) and business regulations $(G R)$ have a positive and significant marginal effect on SMEs product innovation, which were also found with the full sample. It is important to note that most of the food and agribusiness SMEs were proprietary firms, which focus on product innovation with regulatory compliance for their business survival. Our results further suggest that the findings are consistent even when we disaggregate our full sample into SMEs. This shows that our results are robust.

Thus, out of 7 independent variables belonging to internal factors of the firms, two explanatory variables firm type (FTYPE) and internal R\&D (IRD) - show a significant impact on product innovation for all firms, while firm type (FTYPE) and capacity utilization (CU) show a significant impact for SMEs. The analysis indicates that food and agribusiness firms with a sole proprietorship are 15.6\% (for all firms) and 13.4\% (for SMEs) more likely to adopt a product innovation to compete and sustain in the market for the longer term. Sole proprietorship firms are normally innovating their products to improve the product quality to keep pace with large firms. The results from the full sample of food and agribusiness firms indicate that internal $\mathrm{R} \& \mathrm{D}(I R D)$ is a positive influencer of product innovation, whereas this coefficient was not significant for SMEs. Instead, SMEs with lower capacity utilization focus more on product innovation. As SMEs have limited capabilities for internal R\&D investment, proper support for enhancing IRD will certainly help SMEs adopting product innovation. Therefore, Hypothesis 2, which states that internal factors within the firms have a significant influence on the level of product innovation among food and agribusiness enterprises is partially accepted. This implies that proprietorship firms with less capacity utilization for SMEs while proprietorship firms with internal investment in R\&D for the overall sample are likely to innovate their food products.

It is argued that the food and agribusiness system can only be transformed if all the involved parties, including banks, customers, members, and stakeholders, join forces and work together in achieving the organizational goals. Out of eight collaborative factors, four factors - international certification, cooperation for innovation, collaboration with suppliers, and trade associations - are significantly related to product innovation among overall food and agribusiness firms. However, SMEs are found to be less likely to collaborate for product innovation. These collaborations take time and money, so it is likely that most SMEs lack resources to collaborate with leading firms or the payment for the costs of product certification. They may be hesitant to share their trade secrets too. It is clear from the analysis that food and agribusiness firms having an international quality certification, collaborating with suppliers, and actively participating in the programs of trade associations are more likely to adopt product innovation. However, the regression coefficient for cooperation in innovation is negative and significant for the full sample and SMEs, which implies that 
firms seeking external help for innovation are less likely to adopt product innovation. Furthermore, these coefficients are highly significant for both groups. Cooperating with other firms may not generate product innovations but instead focus on other areas to improve competitiveness such as process technology, firm organization (such as a joint venture), or even market entry. So, Hypothesis 3, which states that collaborative factors have a significant impact on the level of product innovation among food and agribusiness enterprises, is partially accepted.

The business regulations $(G R)$ and market externalities $(E E)$ as external factors indicate the significant marginal impact on product innovation for the full sample. A positive and significant marginal effect of business regulations $(G R)$ implies that many food and agribusiness firms innovate their products to meet regulatory compliance, while market externalities (such as competition, political instability, and corruption) are negatively affecting their product innovation. Therefore, Hypothesis 4, which states that external factors have a significant impact on the level of product innovation among food and agribusiness enterprises, is accepted. This implies that product innovation in food and agribusiness firms are affected by external factors.

The summary of hypotheses testing result is given in Table 5. This study tried to identify the potential determinants of product innovation in food and agribusiness enterprises in India, where innovation is at a nascent stage and the majority of firms are still not able to capitalize on the power of internal, collaborative, and external factors in enhancing the level and nature of innovations in their enterprises.

\section{Conclusions and managerial implications}

Food and agribusiness firms in India are going through a transformation phase to formulate growth strategies for their businesses. The food and agribusiness segment is the single largest sector in India and it is growing rapidly. SMEs have emerged as one of the highly vibrant and dynamic parts of the Indian economy, but it has particular needs in terms of policy focus for its growth and development. A separate Ministry of Micro, Small \& Medium Enterprises under the Government of India has been established to address policy issues affecting MSMEs as per the provisions of the Micro, Small and Medium Enterprises Development (MSMED) Act, 2006. The Indian government estimates that there are about 51 million micro, small and medium enterprises, with about $7 \%$ of these enterprises belonging to the food and agribusiness sector, accounting for about $8 \%$ of the country's employment.

Table 5. Summary of hypotheses testing.

\begin{tabular}{|c|c|}
\hline Hypotheses & Inference \\
\hline $\begin{array}{l}\text { H1: The product innovation in the food and } \\
\text { agribusiness sector is significantly associated with } \\
\text { the size of the enterprises. }\end{array}$ & $\begin{array}{l}\text { Supported - comparatively higher percentage of large } \\
\text { firms }(76.8 \%) \text { are focusing on product innovation as } \\
\text { compared to smaller firms }(51.3 \%) \text {. }\end{array}$ \\
\hline $\begin{array}{l}\text { H2: Internal factors within the firms have a significant } \\
\text { influence on the level of product innovation } \\
\text { among food and agribusiness enterprises. }\end{array}$ & $\begin{array}{l}\text { Partially supported - proprietorship firms with less } \\
\text { capacity utilization for SMEs while proprietorship firms } \\
\text { with internal investment in research \& development for } \\
\text { the overall sample are likely to innovate products. }\end{array}$ \\
\hline $\begin{array}{l}\text { H3: Collaborative factors among enterprises } \\
\text { significantly affect the level of product innovation } \\
\text { among food and agribusiness enterprises. }\end{array}$ & $\begin{array}{l}\text { Partially supported - international certification, } \\
\text { cooperation for innovation, collaboration with suppliers, } \\
\text { and trade associations - are significantly related to product } \\
\text { innovation among overall food and agribusiness firms. }\end{array}$ \\
\hline $\begin{array}{l}\text { H4: External factors for the firms have a significant } \\
\text { bearing on the level of product innovation among } \\
\text { food and agribusiness enterprises. }\end{array}$ & $\begin{array}{l}\text { Supported - the business regulations }(G R) \text { and market } \\
\text { externalities }(E E) \text { as external factors indicate the } \\
\text { significant marginal impact on product innovation. }\end{array}$ \\
\hline
\end{tabular}


Food and agribusiness SMEs have huge potential to uplift the agricultural economy, generate employment, and strengthening export earnings. However, these SMEs are facing stiff competition from large global and national conglomerates who can spend significant amounts of money in their R\&D to innovate their products. It is clear from the analysis that product innovation is more prominent in large enterprises as compared to SMEs $-77 \%$ of large food and agribusiness firms have reported a product innovation compared to only $51 \%$ of small and medium firms. Furthermore, SMEs are less diversified in the types of innovations that are adopted. They focus on quality innovations while larger firms have more aims for their innovations. This could imply that SMEs have untapped potential for product innovation if they focus on capacity building and training that can innovate products by having new inputs, better product features, and new technologies to gain a competitive advantage. A closer look at the nature of product innovation indicates that SMEs are primarily focusing on improving the quality of products through innovation, which could help them to compete with the large firms in the market effectively, while large firms focus on diversification through adding new inputs, attributes, and technology.

The results of the regression analysis show an encouraging insight for food and agribusiness SMEs in particular and overall food and agribusiness firms in general. Individual, proprietor-managed firms (which predominate among SMEs) are more likely to adopt product innovation and they are less likely to collaborate with external stakeholders in the process of innovating their products. It seems that product innovation in SMEs is still individual-driven and not business-driven as most of the SMEs belong to proprietorship firms. Time constraints on the part of management could be a reason for this result. It is interesting to note the product innovation of SMEs is negatively impacted by factors such as capacity utilization, cooperation for innovation, and market externalities. This implies that higher capacity utilization among SMEs reduces the chance of product innovation probably due to scarcity of resources with these enterprises, while SMEs are perceived to be risk-prone for external collaboration for innovation and coping with the market externalities. However, the analysis of the overall response of food and agribusiness firms indicates that firm type, internal $\mathrm{R} \& \mathrm{D}$, cooperation for innovation, collaboration with suppliers, and membership in a trade association, business regulations, and market externalities are significantly influencing the product innovation. Business regulations have a positive and significant impact on product innovation for all food and agribusiness firms including SMEs provides positive support to implementing regulations for enhancing the capabilities of food and agribusiness firms.

There could be a role for government in improving the environment for product innovations by SMEs. Enhanced policies, regulations, and legal enforcement that protect SMEs when they collaborate with other companies could provide more protection for SMEs when they work with other firms or organizations with respect to product innovations. These smaller companies seem to view the external environment (corruption, lax law enforcement, political instability) to overcome when it comes to innovations. Managers should present these fears to government to make sure that regulations and policies positively affect SME incentives.

This study provides key insights on how food and agribusiness small and medium scale enterprises (SMEs) are responding to the changing business environment and competing with large firms through product innovation. An understanding of product innovation adopted by food and agribusiness SMEs may help in designing a better policy framework by India's Ministry of Micro, Small \& Medium Enterprises. An analysis of factors affecting the level of adoption of product innovations may help the firms to better formulate their business strategy and enable them to compete in the emerging market environment. This study not only provides a clear direction to SME managers for adopting incremental innovations through product quality enhancements but also to innovate more radically by launching health and wellness food products. Overall, SMEs can overcome some of their difficulties in product innovation by using these groups to help guide their investments. There is an urgent need for building the business capacity of SMEs and enabling them to strengthen their capabilities to achieve competitive advantage through product innovation.

This study is based on large surveys conducted by the World Bank, i.e. the Enterprise Survey and the India Innovation Follow-up Survey undertaken in the year 2014, which have provided limited choices in selecting 
the variables for the analysis. 294 Indian food and agribusiness firms were considered for this analysis after merging the datasets of both surveys based on the International Standard Industrial Classification. As there are no other rounds of such a survey in the recent year, there is the scope of conducting a dedicated survey across food and agribusiness firms in India with a large sample size for mapping the process of innovations across sub-sectors such as food, agricultural inputs, and services. This would allow researchers to focus on specific firms within the agricultural sector (such as food processing firms) and track them over time to analyze their innovations. This would provide a better view of how Indian firms adapt and innovate over time and might discover how SMEs turn into larger-scale firms. There is also scope to improve the regression model by adding more explanatory variables as determinants of product innovation. Most of the independent variables used in the study are probably endogenous to the firms so the explanation of the results is primarily predicting the direction of the relationships. Moreover, future research on the determinants of product innovation could be enriched through performing heterogeneous effects analysis by looking at the differences between food and agribusiness SMEs across industries, sizes and types of business innovations.

\section{References}

Abdirahman, Z.-Z., M. Cherni and L. Sauvée. 2014. Networked innovation: a concept for knowledge-based agrifood business. Journal on Chain and Network Science 14(2): 83-93. https://doi.org/10.3920/ JCNS2014.x003

Ali, J. 2016. Performance of small and medium-sized food and agribusiness enterprises: evidence from Indian firms. International Food and Agribusiness Management Review 19(4): 53-64.

Antikainen, M. and M. Niemelä. 2014. How to co-create local food products and services with consumers? The XXV ISPIM Conference - Innovation for Sustainable Economy \& Society. June 8-11, 2014. ISPIM, Dublin, Ireland.

Avermaete, T., V.E. Jacques, J. Morgan and N. Crawford. 2003. Determinants of innovation in small food firms. European Journal of Innovation Management 6(1): 8-17.

Ayyagari, M., T. Beck and A. Demirguc-Kunt. 2007. Small and medium enterprises across the globe. Small Business Economics 29(4): 415-434.

Azanedo, L., G. Garcia-Garcia, J. Stone and S. Rahimifard. 2020. An overview of current challenges in new food product development. Sustainability 12(8): 10-13. https://doi.org/10.3390/SU12083364

Babutsidze, Z. 2016. Innovation, competition and firm size distribution on fragmented markets. Journal of Evolutionary Economics 26(1): 143-169.

Baregheh, A., J. Rowley, S. Sambrook and D. Davies. 2012a. Food sector SMEs and innovation types. British Food Journal 114(11): 1640-1653.

Baregheh, A., J. Rowley, S. Sambrook and D. Davies. 2012b. Innovation in food sector SMEs. Journal of Small Business and Enterprise Development 19(2): 300-321.

Bayona-Saez, C., C. Cruz-Cázares, T. García-Marco and M. Sánchez García. 2017. Open innovation in the food and beverage industry. Management Decision 55(3): 526-546.

Berry, A., E. Rodriguez and H. Sandee. 2001. Small and medium enterprise dynamics in Indonesia. Bulletin of Indonesian Economic Studies 37(3): 363-384.

Bettiga, D. and F. Ciccullo. 2018. Co-creation with customers and suppliers: an exploratory study. Business Process Management Journal 25(2): 250-270.

Bhardwaj, B.R. 2019. Influence of knowledge management on product innovation by intrapreneurial firms. Global Knowledge, Memory and Communication 69(1-2): 38-57.

Bhattacharya, M. and H. Bloch. 2004. Determinants of innovation. Small Business Economics 22(2): 155-162.

Bhuiyan, A.B., J. Said, M.D. Ismail, M.F.M. Jani and D.Y.G. Fie. 2016. The innovation drivers, strategies and performance of food processing SMEs in Malaysia. Malaysian Journal of Society and Space 12(2): 154-166.

Blog, C.A. 2017. How between-firm collaboration impacts on innovation: the significance of proximity dimensions. Strategic Direction 33(6): 29-31.

Bougrain, F. and B. Haudeville. 2002. Innovation, collaboration and SMEs internal research capacities. Research Policy 31(5): 735-747. 
Brouwer, E. and A. Kleinknecht. 1996. Firm size, small business presence and sales of innovative products: a micro-econometric analysis. Small Business Economics 8(3): 189-201

Busse, M. and R. Siebert. 2018. The role of consumers in food innovation processes. European Journal of Innovation Management 21(1): 20-43.

Capitanio, F., A. Coppola and S. Pascucci. 2009. Indications for drivers of innovation in the food sector. British Food Journal 111(8): 820-838.

Capitanio, F., A. Coppola and S. Pascucci. 2010. Product and process innovation in the Italian food industry. Agribusiness: an International Journal 26(4): 503-518.

Caridà, A. and M. Colurcio. 2014. Collaborative innovation in food SMEs: a practice approach. Archives of Business Research 2(4): 138-149.

Chang, Y.Y., M. Hughes and S. Hotho. 2011. Internal and external antecedents of SMEs' innovation ambidexterity outcomes. Management Decision 49(10): 1658-1676.

Colurcio, M. and T. Russo-Spena. 2013. Collaborative innovation - a focus on food SMEs. Food Industry. IntechOpen, London, UK.

Cook, P. and F. Nixson. 2000. Finance and small and medium-sized enterprise development. Working Paper Series No. 14. Finance and Development Research Programme, Institute for Development Policy and Management, University of Manchester, Manchester, UK.

Damanpour, F. and M. Schneider. 2009. Characteristics of innovation and innovation adoption in public organizations: assessing the role of managers. Journal of Public Administration Research and Theory 19(3): 495-522.

De Martino, M. and F. Magnotti. 2018. The innovation capacity of small food firms in Italy. European Journal of Innovation Management 21(3): 362-383.

Dhamvithee, P., B. Shankar, A. Jangchud and P. Wuttijumnong. 2005. New product development in Thai agro-industry: explaining the rates of innovation and success in innovation. International Food and Agribusiness Management Review 8(3): 1-20.

Dooley, L., B. Kenny and M. Cronin. 2016. Interorganizational innovation across geographic and cognitive boundaries: does firm size matter? R\&D Management 46: 227-243.

Dries, L., S. Pascucci, Á. Török and J. Tóth. 2013. Open innovation: a case-study of the Hungarian wine sector. EuroChoices 12(1): 53-59.

El Manzani, Y., M.L. Sidmou and J. Cegarra. 2019. Does IS0 9001 quality management system support product innovation? An analysis from the sociotechnical systems theory. International Journal of Quality and Reliability Management 36(6): 951-982.

Falahat, M., T. Ramayah, P. Soto-Acosta and Y.Y. Lee. 2020. SMEs internationalization: the role of product innovation, market intelligence, pricing and marketing communication capabilities as drivers of SMEs' international performance. Technological Forecasting and Social Change 152: 119908.

Felin, T., K.R. Lakhani and M.L. Tushman. 2017. Firms, crowds, and innovation. Strategic Organization 15(2): 119-140.

Feranita, F., J. Kotlar and A. De Massis. 2017. Collaborative innovation in family firms: past research, current debates and agenda for future research. Journal of Family Business Strategy 8(3): 137-156.

Fernández-Esquinas, M., M. Van Oostrom and H. Pinto. 2017. Key issues on innovation, culture and institutions: implications for SMEs and micro firms. European Planning Studies 25(11): 1897-1907.

Fertő, I., A. Molnár and J. Tóth. 2016. Borderless ideas-open innovation in the Hungarian food chain. British Food Journal 118(6): 1494-1515.

Filieri, R. 2013. Consumer co-creation and new product development: a case study in the food industry. Marketing Intelligence \& Planning 31(1): 40-53.

Fouad, F., A. Tourabi and G. Lakhnati. 2018. The innovation process impact on the new product performance: a case study. International Journal of Innovation Science 10(3): 385-412.

Garst, J., V. Blok, L. Jansen and O.S.W.F. Omta. 2017. Responsibility versus profit: the motives of food firms for healthy product innovation. Sustainability 9(12): 2286. https://doi.org/10.3390/su9122286

Hansen, J.A. 1992. Innovation, firm size, and firm age. Small Business Economics 4(1): 37-44. 
Haus-Reve, S., R.D. Fitjar and A. Rodríguez-Pose. 2019. Does combining different types of collaboration always benefit firms? Collaboration, complementarity and product innovation in Norway. Research Policy 48(6): 1476-1486.

Herrmann, R. 1997. The distribution of product innovations in the food industry: economic determinants and empirical tests for Germany. Agribusiness: an International Journal 13(3): 319-334.

Hoegl, M. and S.M. Wagner. 2005. Buyer-supplier collaboration in product development projects. Journal of Management 31(4): 530-548.

Hong, S., L. Oxley, P. McCann and T. Le. 2016. Why firm size matters: investigating the drivers of innovation and economic performance in New Zealand using the Business Operations Survey. Applied Economics 48(55): 5379-5395.

Hoyer, W.D., R. Chandy, M. Dorotic, M. Krafft and S.S. Singh. 2010. Consumer cocreation in new product development. Journal of Service Research 13(3): 283-296.

Hutahayan, B. and S. Yufra. 2019. Innovation speed and competitiveness of food small and medium-sized enterprises (SME) in Malang, Indonesia: creative destruction as the mediation. Journal of Science and Technology Policy Management 10(5): 1152-1173.

Jaeger, S.R., K.L. Rossiter, W.V. Wismer and F.R. Harker. 2003. Consumer-driven product development in the kiwifruit industry. Food Quality and Preference 14(3): 187-198.

Jozsef, T. and F. Imre. 2017. Innovation in the Hungarian food economy. Agricultural Economics 63(1): 43-51. Ko, W.W.J., G. Liu, I.K. Ngugi and C. Chapleo. 2018. External supply chain flexibility and product innovation performance: a study of small and medium-sized UK-based manufacturers. European Journal of Marketing 52(9-10): 1981-2004.

Kuzminov, I., P. Bakhtin, E. Khabirova, M. Kotsemir and A. Lavrinenko. 2018. Mapping the radical innovations in food industry: a text mining study. National Research University Higher School of Economics (HSE), Moscow, Russian Federation.

Lefebvre, V.M., H. De Steur and X. Gellynck. 2015. External sources for innovation in food SMEs. British Food Journal 117(1): 412-430.

Lin, C.Y-Y. 1998. Success factors of small- and medium-sized enterprises in Taiwan: an analysis of cases. Journal of Small Business Management 36(4): 43-56.

Lundvall, B.-A. 1992. National systems of innovation: towards a theory of innovation and interactive learning. Frances Pinter, London, UK.

Macdonald, S., D. Assimakopoulos and P. Anderson. 2007. Education and training for innovation in SMEs: a tale of exploitation. International Small Business Journal 25(1): 77-95.

Madzík, P. 2019. Capture and evaluation of innovative ideas in early stages of product development. TQM Journal 31(6): 908-927.

Manresa, A., A. Bikfalvi and A. Simon. 2019. The impact of training and development practices on innovation and financial performance. Industrial and Commercial Training 51(7-8): 421-444.

Mark-Herbert, C. 2004. Innovation of a new product category - functional foods. Technovation 24(9): 713-719.

Markovic, S., M. Jovanovic, M. Bagherzadeh, C. Sancha, M. Sarafinovska and Y. Qiu. 2020. Priorities when selecting business partners for service innovation: the contingency role of product innovation. Industrial Marketing Management 88: 378-388.

Martinez, M.G. and J. Briz. 2000. Innovation activities in the Spanish food and drink industry. International Food and Agribusiness Management Review 3: 155-176.

McAdam, M., R. McAdam, A. Dunn and C. McCall. 2016. Regional horizontal networks within the SME agri-food sector: an innovation and social network perspective. Regional Studies 50(8): 1316-1329.

Mention, A.L. 2011. Cooperation and coopetition as open innovation practices in the service sector: which influence on innovation novelty? Technovation 31(1): 44-53.

Minarelli, F., M. Raggi and D. Viaggi. 2014. Distinguishing the innovation behaviour of micro, small and medium food enterprises. Journal on Chain and Network Science 14(2): 95-102. https://doi. org/10.3920/JCNS2014.x004

Ministry of Micro, Small and Medium Enterprises, 2016. Annual report (2015-16). Government of India, New Delhi, India. 
Muscio, A., G. Nardone and A. Dottore. 2010. Understanding demand for innovation in the food industry. Measuring Business Excellence 14(4): 35-48.

Narula, R. 2004. R\&D collaboration by SMEs: new opportunities and limitations in the face of globalisation. Technovation 24(2): 153-161.

Nazzaro, C., M. Lerro, M. Stanco and G. Marotta. 2019. Do consumers like food product innovation? An analysis of willingness to pay for innovative food attributes. British Food Journal 121(6): 1413-1427.

Nor, G.M, A.B. Bhuiyan, J. Said and U. Teknologi. 2016. Innovation barriers and risks for food processing SMEs in Malaysia: a logistic regression analysis. Malaysian Journal of Society and Space 2(2): 167-178.

Powell, W.W., K.W. Koput and L.I. Smith-Doerr. 1996. Interorganizational collaboration and the locus of innovation: networks of learning in biotechnology. Administrative Science Quarterly 41(1): 116-145.

Ramadani, V., R.D. Hisrich, H. Abazi-Alili, L.P. Dana, L. Panthi and L. Abazi-Bexheti. 2019. Product innovation and firm performance in transition economies: a multi-stage estimation approach. Technological Forecasting and Social Change 140: 271-280.

Raymond, L. and J. St-Pierre. 2010. R\&D as a determinant of innovation in manufacturing SMEs: an attempt at empirical clarification. Technovation 30(1): 48-56.

Restrepo-Morales, J.A., O.L. Loaiza and J.G. Vanegas. 2019. Determinants of innovation: a multivariate analysis in Colombian micro, small and medium-sized enterprises. Journal of Economics, Finance and Administrative Science 24(47): 97-112.

Rhee, J., T. Park and D.H. Lee. 2010. Drivers of innovativeness and performance for innovative SMEs in South Korea: mediation of learning orientation. Technovation 30(1): 65-75.

Rogers, M. 2004. Networks, firm size and innovation. Small Business Economics 22(2): 141-153.

Santarelli, E. and A. Sterlacchini. 1990. Innovation, formal vs. informal R\&D, and firm size: some evidence from Italian manufacturing firms. Small Business Economics 2(3): 223-228.

Santoro, G., D. Vrontis and A. Pastore. 2017. External knowledge sourcing and new product development: evidence from the Italian food and beverage industry. British Food Journal 119(11): 2373-2387.

Segarra-Ciprés, M. and J.C. Bou-Llusar. 2018. External knowledge search for innovation: the role of firms' innovation strategy and industry context. Journal of Knowledge Management 22(2): 280-298.

Simmons, G.J., M.G. Durkin, P. McGowan and G.A. Armstrong. 2007. Determinants of internet adoption by SME agri-food companies. Journal of Small Business and Enterprise Development 14(4): 620-640.

Siriwongwilaichat, P. and R.J. Winger. 2004. Technical knowledge for food product innovation in Thailand. Agribusiness: an International Journal 20(3): 233-252.

Siro, I., E. Kapolna, B. Kapolna and A. Lugasi 2008. Functional food. Product development, marketing and consumer acceptance - a review. Appetite 51(3): 456-467.

Snihur, Y. and J. Wiklund. 2018. Searching for innovation: product, process, and business model innovations and search behavior in established firms. Long Range Planning 52(3): 305-325. https://doi.org/10.1016/j. lrp.2018.05.003

Søndergaard, H.A. 2005. Market-oriented new product development. European Journal of Innovation Management 8(1): 79-90.

Strobel, N. and J. Kratzer. 2017. Obstacles to Innovation for SMEs: evidence from Germany. International Journal of Innovation Management 21(3): 1-28.

Suwannaporn, P. and M. Speece. 2000. Continuous learning process in new product development in the Thai food-processing industry. British Food Journal 102(8): 598-614.

Suwannaporn, P. and M.W. Speece. 2010. Assessing new product development success factors in the Thai food industry. British Food Journal 112(4): 364-386.

Teruel, M. and S.B. Agustí. 2017. The link between gender diversity and innovation: what is the role of firm size? International Review of Entrepreneurship 15(3): 319-340.

Toselli, M. 2017. Knowledge sources and integration ties toward innovation. A food sector perspective. Eurasian Business Review 7(1): 43-65.

Traill, W.B. and M. Meulenberg. 2002. Innovation in the food industry. Agribusiness: an International Journal 18(1): 1-21. 
Triguero, A., D. Córcoles and M.C. Cuerva. 2013. Differences in innovation between food and manufacturing firms: an analysis of persistence. Agribusiness: an International Journal 29(3): 273-292.

Trott, P. and C. Simms. 2017. An examination of product innovation in low- and medium-technology industries: cases from the UK packaged food sector. Research Policy 46(3): 605-623.

Trott, P. and D. Hartmann. 2009. Why 'open innovation' is old wine in new bottles. International Journal of Innovation Management 13(4): 715-736.

Ueasangkomsate, P. and A. Jangkot. 2018. Enhancing the innovation of small and medium enterprises in food manufacturing through Triple Helix Agents. Kasetsart Journal of Social Sciences 40(2): 1-9.

Van Kleef, E., H.C.M. Van Trijp and P. Luning. 2005. Consumer research in the early stages of new product development: a critical review of methods and techniques. Food Quality and Preference 16(3): 181-201.

Vancauteren, M. 2018. The effects of human capital, R\&D and firm's innovation on patents: a panel study on Dutch food firms. Journal of Technology Transfer 43(4): 901-922.

Winger, R. and G. Wall. 2006. Food product innovation - a background paper. Agricultural and Food Engineering Working Document 22. FAO, Rome, Italy.

World Bank. 2014. World Bank Enterprise Survey Database. World Bank, Washington, DC, USA. Available at: https://www.enterprisesurveys.org/en/citing-the-data

Xu, H. 2020. Corporate social responsibility, product innovation, and product line. Nankai Business Review International 11(2): 171-190.

Yes Bank. 2016. Confederation of Indian industry make in India opportunities in food processing sector. Yes Bank, Mumbai, India. Available at: https://www.yesbank.in/pdf/make_in_india-_opportunities_ in_food_processing_sector.pdf

Ziggers, G.W. 2005. Radical product innovation in the Dutch food industry. Journal of Food Products Marketing 11(3): 43-65. 